\title{
A Study on the Aesthetic Ideology in Carl Sandburg's Nature Poems
}

\author{
Shaojun Duan \\ School of Foreign Languages \\ Kunming University \\ Kunming, China \\ Email: duanshaojun2709@126.com
}

\begin{abstract}
Carl Sandburg was an outstanding modern American poet, many of his poems voice the development of the American society and express and deliver his concern towards the civilians and those poems received a warm welcome from the populace as well as the academic world. However, his nature poems which convey considerable aesthetic thought and which portray grand beauty do not gain much attention from the public. This paper, under the guidance of Denis Diderot's aesthetic theory-- Beauty Lies in Relation, tries to analyze Carl Sandburg's most artistically designed nature poems, aiming at revealing his aesthetic ideology in three layers: The Internal Relation of a Matter Itself, The Exterior Linkage between Things, and The Other Beauty. Meanwhile, to a certain degree, this paper may expose to the readers the charm of the poems. Hopefully, it will arouse certain interest of other researchers to carry on further studies on his nature verses to bring to readers a more complete picture of this poet and his works.
\end{abstract}

Keywords: Carl Sandburg; aesthetic ideology; nature poems; beauty

\section{INTRODUCTION}

Carl Sandburg was born in Galesburg on January 6, 1878, and passed away at his North Carolina home on July 22,1967 . His ashes, as he had requested, were sent back to his birthplace. He was a writer, editor and biographer, best known for his poetry. He won three Pulitzer Prizes, two for his poetry and another for a biography of Abraham Lincoln. Carl was the second child of his poor family. $\mathrm{He}$ had six siblings, and his parents were immigrants from Sweden. And this background explains well of Carl's labyrinthine life. He never received formal education and started working from the time when he was a young boy. Carl left school following his graduation from grade eight in 1891 and spent ten years working a variety of jobs. "He delivered milk, harvested rice, laid bricks, threshed wheat in Kansas, and shined shoes in Galesburg's Union Hotel before traveling as a hobo in $1897^{[1] 3}$. His humble origin and his working experiences at the bottom of the society provided him with a good deal of writing materials and led him to show lifelong concern for the ordinary people and greatly influenced his writing style and political views. As a socialist and a poet with democratic spirit, Carl's poetic aim was simple, and it is to write "simple poems for simple folks". The highest ideal of his life was to become "the voice of the people" ${ }^{[2] 70}$. It is then understandable that a large numbers of his poems had devoted themselves to this theme. This paper, under the guidance of Denis Diderot's aesthetic theory-- Beauty Lies in Relation, tries to analyze Carl Sandburg's most artistically designed nature poems, aiming at revealing his aesthetic ideology in three layers: The Internal Relation of a Matter Itself, The Exterior Linkage between Things, and The Other Beauty.

\section{THE INTERNAL RELATION OF A MATTER ITSELF}

Of the first layer of Diderot's aesthetic idea BLIR (short for "beauty lies in relation"), he noted the authentic beauty, which is formulated by the intrinsic relations of an item itself, and that could be also put as the secret essence of beauty. ${ }^{[3] 1}$ Sandburg shared the similar point of view but only a little bit the other way around, for he sensed beauty first and penetrated into relation later and headed back to beauty again. To him, anything which in some way is considered as the beautiful bears the nature of beauty within itself, and this nature is shaped by its own intrinsic rules and it beautifies the matter to a more breathtaking realm.

In the poem "Autumn Movement" [4], Sandburg observed the gorgeousness of fall and discovered the nature of its beauty lies in its momentariness, the predestined fate of it. His destiny is inevitable, and thus it makes beauty even more lovable. "Autumn Movement" shows the change in leaves and flowers and reflects the changes of the late autumn and the early winter. All these changes vanish in a second and none of them last. And "I", the beholder of these changes, thinking of their old fairness which now is nowhere to be seen, could not help crying. Changes take the old things away, and away with all the old beautiful memories. A first glance of the poem might give the readers the following impression: for the cornflowers, they will have another season to spring their beauty again although now the northwest wind has torn their charming looks. However, the new things will not be the same as that of the old. The old has gone, and the new will be another old stuff. They all have their loveliness, and loveliness will not last long. Therefore, no beautiful thing really "lasts". The moment a flower is at its fullest blossom; its final time will be around the corner. And it is due to this nature that beauty itself is so touching and impressive. This pathetic character is inborn, and beauty is thus destined to be the non-lasting type, and "I" could do nothing about it. That's why "i cried over beautiful things", because "I" knew "no beautiful thing lasts".

The next poem "Nocturne in a Deserted Brickyard" [4] which bears the mark "beauty lies in the beautiful itself" tastes rather different from the previous one. Despite the fact that this poem took its picture on a deserted brickyard and it was by night, the whole scene is completely free 
from being murky grey and the lines convey no sentiment at all, and the poet lead the readers to a wonderland.

This short poem contains one stanza with only seven lines altogether, nevertheless, it spreads the vivid view of a tableau to more than seven square meters wide. Sandburg noted the flowing beauty of the moonlight in this verse, and the readers could perceive that everything under the moonbeam is all covered with tenderness. The moon's stuff, the moonlight, is pulled open by an invisible hand as if it was a curtain, and as the curtain is pulled to opposite directions, unfolding before the reader's eyes a tranquil dreamlike nocturne, a night scene. As the light of the moon casts on the sand, which is shimmering because the night is not in thorough darkness, the reader follows the heels of it. It is a "trick" of the moon and as well as of the poet. By the words "runs", "out to", "under" and "round", Sandburg leads the viewer into the picture. And all the pleasing scenery along the way-— the glimmering sand, the shadows under the willows- - draws him into the last intoxicating wonder, the dreaming pansy, and within the blink of an eye, the guide is gone. The viewer is left alone with himself, wondering about the pansy. And meanwhile the moonlight lingers on. The moon sheds its liquid light silently over the night and makes a deserted brickyard divine. It runs on the sand, rambles over the willows and crosses the pond and a notturno is composed. The moonshine in this poem is a brush; it colors things and makes fantastic view. It is capable of creating incredible beauty out of the common plain things and the reason all lies in itself — - the moonlight alone is a thing of beauty, and it bears the nature of morbidezza.

\section{THE EXTERIOR LINKAGE BETWEEN THINGS}

Both Diderot and Sandburg perceived beauty through the interior bond of a matter itself, but will they stand on the same ground when it comes to the exterior linkage between different things? Diderot mentioned in his BLIR the behold beauty, which is reached by the perception of the interconnections among separate articles. Sandburg, though not a philosopher, delivered a massage of aesthetic philosophy by way of poetic lines. And this time, they two think much alike.

Previously, "Autumn Movement" and "Nocturne in a Deserted Brickyard" unveiled that the beautiful itself does inhere some attractive nature and present the eyes a feast, like a flash of splendor, a rain of petals, the autumn movement, or, the moonlight. But, when beauty brings up connections which further link to something that are more tempting than the beautiful itself, the whole realm of the view will be extended. It is in some way like the old Chinese saying, "Blue comes from the indigo plant but is bluer than the plant itself - the pupil surpasses the master". Here, the "master" is the beautiful itself, and the pupil, the contact. Sandburg touched and painted connections of this kind in the four poems below.

The first piece of this group, "Under the Harvest Moon" ${ }^{[4]}$. This verse is separated into two stanzas; the first stanza contains eight lines, and the second, nine lines. This poem moves around death and love, but the latter far outweighs the former. By the very first line of the first stanza, Sandburg draws the reader into the poetic view. It is night, the harvest moon is in the sky and the garden showers in the moonlight. Whoever is personally on the scene, he or she is inclined to be affected by its serenity. And here as the narrator of the moonlit night, the poet himself was touched and translated his feelings into a dynamic drawing to the reader-" Death, the gray mocker, /Comes and whispers to you /As a beautiful friend /Who remembers." Sandburg associates the quiet peaceful night with death, and death in this situation appears to be gentle and tender like an old beautiful friend. The mind is then as still as a lake and all the links that death has drawn out turn to fine memories. The second stanza, as a balance, brings forth "love". The symbol of love, rose, could it be a link of the stanza ahead? Is it the recollection of the past? Or, the second stanza as a whole is a link of the former? No one can tell. Maybe Sandburg himself was not sure about that. But since he made it clear that his verses were simple and they were for simple folks, here it is acceptable to take the "summer roses" as another ordinary natural scene and give these puzzles a break and save them for the later discussion. So, the second stanza exposes the reader to another painting: the summer roses as a whole is a pretty maid in her bright red dress. And at dusk, this young lady hides herself among the wild red leaves (of the roses), waiting for her lover ("you"). As you settle yourself under the roses, the petals meet your head and shoulders, which remind you of your love, who use to hide behind you as the roses and who touches you when you arrive and asks you beautiful, unanswerable questions. At this point, the summer roses here is the second image love who no longer exists. The moonlight scene puts a branch to death, and death stirs up the memory of love and life, and the summer roses recall love as a response. One links to another, the whole picture is displayed. Love and death then become the highlight of the night. And the riddles all have their solutions now. "Under the Harvest Moon" depicts the abstract beauty through the concrete one and concatenates them by their delicate similarities. While in the poem "Back Yard", Sandburg drew a harmonious picture via simply putting several specific scenes into one frame, revealing the beauty of the relations among them. If Diderot took Under the Harvest Moon as a glass of fragrant claret, he would find that Back Yard tastes like heaven.

"Back Yard" [4] contains five stanzas and each one presents a delightful scene. To capture this piece, one shall first have a holistic view about it. The first stanza spreads a vast view of a summer night when the moonlight covers all in silver. And next, the background music of this endearing night comes to the reader's ears when the Italian boy sends melody to the air, and in the turning of a hand, a young couple throw kisses. Under the moonlight, the peace of an old man's dream is another enjoyable scene. And "I", as the outsider who admires all these scenes, am unwilling to leave, therefore making an appeal to the moon "shine on, o moon; shake out more and more silver changes". The moonlight, the music, the romantic lovers, and the old man dreaming in a cherry tree and again the moonlight, all these things, each bears unique beauty and 
each is inseparable from the other in virtue of the relations that connect them. The moonlight is charming indeed, but it will not bear that much glamour without the mellifluous music, the romantic love, or the peaceful dream, and the others vice versa. And all of them putting up together through their ties create a harmonious piece of art, intoxicating and fascinating. The whole marvelous scene makes "me" wonder and "I" want to see more. In Back Yard, Sandburg sang for the harmony of the beautiful things and appreciated the beauty they composed through relations. This piece is a perfect example of Diderot's aesthetic belief "the behold beauty" as in the BLIR. This poem also conveys certain praises for the beauty of simple life, as the music and love and dream listed in the verse are simple happiness for the common folks. He did voice for the people. And as a nature lover himself, he was always ready to share the beauty he perceived.

Comes next, "Between Two Hills" ${ }^{[4]}$. Two stanzas constitute this poem, and the simplicity of it utters the serenity of the humble life and suggests a harmonious relation between man and nature. Night is falling and darkness is gathering, the air is cooling and dews are taking shape. Somewhere between two hills, an old town could be seen dimly in the evening mist. Houses and trees set each other off, and roofs are caught by corners. Everything seems to be covered by a kind of serene atmosphere. Why there is no light? Where are the inhabitants? What about the children? This remote old town has its night early, and its people have already gone to their sleep, resting in their dreams. The town is in the arms of the hills, and the people live a quiet life - a tuneful drawing about life and natural surroundings. Below the plain surface of this wash painting like poem, Sandburg sang for the simple relation that lies in man and nature. It is in this simple beautiful relation that mankind starts the cultivation of civilization and begins dreaming about a better future. This relation may not as that dazzling as the fairness of a flower, but it conveys the truth of the development of human beings which no blooms can deliver. Sandburg appreciated the harmony of life and considered the peace between man and nature as an art of beauty. Diderot might as well note his head to this idea if he were born a-hundred-year later.

When it comes to the connections that are drawn forth by the natural beautiful things, Sandburg did not forget to mention the beauty of the spirit of the youth who are full of dreams and energy and who are ambitious like the wild sea. Justification of this point, the poem "Young Sea". The piece Young Sea ${ }^{[4]}$ consists of six stanzas with one leads to another. At the very start of the poem, the reader is taken to the seaside, catching a grand view of the waves crashing upon the shore. Forever the sea is on its move, wild with energy and passion, and this vigorous feature reminds the poet the youth who symbolize the strength of life. The sea has its own symbols and words, and only the youth, who are as ambitious as the open sea, have the insight to grasp the meaning. Then why the sea chooses the youth? The third stanza replies, "the sea is young". Choppy and rough the sea is, it remains young, for billows and storms give a rebirth to the sea and erase the old traces.
The continuous movement of the sea, the waves, the wind and all send roars of laughter to "my" ears. The sea is laughing, for the men who ride on it love the sea heartily, although they know that they will die under the blue waters someday. Then comes the fifth stanza, the sea makes its exclamation- "let only the young come", the young know the sea better. And the last stanza, the sea states that it reveals truth "I tell where storms and stars come from". Sandburg did laud and emphasis the wildness and the vigor of the sea, but he put the core of the poem on the youth with whom the sea shares its grand beauty and to whom the sea says the truth. Through the words of the sea, the poet sang for the young people, who are full of dreams and hope and who are abundant in vitality, and it is this spirit that earned them the name "the youth". Beautiful and splendid the sea itself is, it admires the spirit of the youth.

\section{THE OTHER BEAUTY.}

In the third class of BLIR, Diderot stated the fictive (mental) beauty, which touches on the relation between the subject (the observer) and the object and which lays stress on the feelings of the beholder. On the basis of this point, joyousness hears the sound of music in rain and grief gets nothing more than cries. Sadness and happiness can both color a scene in a touching way, and the images they paint are charming to Diderot in their unique styles. But emotions are far more than just joy and sorrow, beyond that, there stand many other members who are as good as them, and some are even more talented. Ease, for example, is one of the most gifted painters, for it clears the eyes and presents the most limpid vision and comforts the soul. Sandburg sang for the humble folks who live a simple life, beauty in his sense means also the simplicity of life. And to capture it, one needs to rest his mind in ease.

To Sandburg, beauty is captured in ease, and any little thing that pleases the eyes or the mind deserves the name "beautiful". In the following four poems, Sandburg introduced to the readers the simple yet impressive beauty of the most ordinary things through the lighthearted moods of different kind. The first piece to be appreciated is, "Wind Song" [4]. With a nostalgic mood and a retrospection of childhood memories, this simple poem exposes the readers to the beauteousness of the wind both visually and aurally. Wind Song starts by the capitalized word "long" and within a second the reminiscent feelings aroused and visions of the past revealed. It was a summer afternoon, and "I" was in an old orchard, resting on the ground under the trees. The person "I" or the poet himself was then perhaps a little boy with wild imaginations, so that the wind could appear in such soft artistic conception in his eyes- - "the wind swept by counting its money and throwing it away". Hardly anyone would think leaves as the money of the wind, but a child or a person who bears childlike romance could, very possibly, do that. For the common majority, they may not even pay the least attention to the wind, let along listening to the wind when it passes by the branches and causes the leaves rustle and fall. Simple and plain as the words seem, they were arranged with aesthetic sense and thus the readers can feel 
the wind with their eyes as well as their ears. The wind passes through the branches and whistles with the sound hoo-hoo, and the trees seem to inquire the wind "who, who are you". A blast is then turned into a conversation between the wind and the trees, and the falling leaves thus wear poetic beauty. Sandburg, or, the person "I" admires and engraves the simple beauty of the wind and the beauteous view the wind creates, and he believes that he is not alone in this aesthetic appreciation, therefore, by the end of the poem, Sandburg asks his readers "who can ever forget listening to the wind go by, counting its money and throwing it away?". Though the voice of the person "I", Sandburg shared a fine piece of memory of natural beauty which was perceived long time ago and dropped a hint that to listen to the wind and to capture its beauty requires a sensitive and relieved mind, and above all, a light mood. Wind Song suggests that beauty is perceivable and reachable in people's everyday life and it asks nothing more than a piece of "loafing" mind. A bright mood finds spark even from the most prosaic things and apart from that it has the power to light the grey sky and assists one to regain confidence as well as dreams. As a great poet who made the determination to speak for the broad masses of the people, Sandburg did not forget to bring hope for the public, and he brought it to them in a breezy way.

The second piece to be appreciated is, "The South Wind Say So" [4]. This piece is composed by ten lines, the first six lines draw forth three items of the spring, the oriole, the new leaves of a bean pole and the crickets, and each of them is led out by the word "if", and all together presenting a view of the coming spring, the first season of the year. The tone of the poem seems to indicate that "we" had a tough year and are now tired and depressed, knowing nowhere to head to, and yet "we" are not in despair. Determined and powerful cries are heard in the last four lines, five "we will" in their entirety stand as ambition and faith of a new life. The parallel structure of the poem constructs a strong sense of emotion with one line waves on the other. Spring is approaching, and the south wind is on its way. If the oriole sings like the year bygone, if the bean pole has its first sprout like the old one and if, even the crickets seem to send the old massages, if all starts like last year, nothing should "we" be afraid of, for "we" will go through them all like what "we" did last year. "Tough time never lasts long, tough people do." The renewal of the seasons symbolizes the hope of the continuation of life. To Sandburg, spring is more than a fair season, it bears hope and inspiration, and it encourages people to move on.

Life would be lifeless without hope, and hope itself is a poetic piece of art. And with dreams in mind, spring comes back to life, thus "we" see a promising day.

A heart at its ease finds life fine and enjoyable and knows the way to explore and admire its beauty from its simplicity. One way to unearth the treasure of life is to be attached to it, and in this way, the discovery of beauty will prove itself an easy matter. Justification of this point could be found in the short poem "June". Sandburg had a deep and pure adoration towards his wife Paula. Walter G. Moss (2009) recorded that Sandburg traveled a lot due to the nature of his work, and every time when he was home again with his wife, knowing she was around, he thought he was in a dreamland, as it was too good to be true. ${ }^{[5]}$ Here in this simple poem, Sandburg was attracted by the enchantment of two petals of the crabapple blossom and the white fluff of a cottonwood. The petals are lovable and the fluff is soft, and when they fall on the hair of his beloved femme, they all bear the charm of grace and elegance. The poem presents an exquisite view: a lovely lady is hoeing in the garden, a blow comes and petals fall and fluff floats, and then all is lost in the beautiful vision. Sandburg noted the glamour in the petals and the fluff because he was in love, the affection he had for Paula enabled him to grasp beauty from the often neglected common things. The poet was then occupied by tenderness, his mind and heart were immersed in the feelings of softness, and his eyes find their way to beauty naturally. A mind at its leisure, a mood with faith, and a feeling in love all help one to find beauty, but this picture of aesthetic perception will not be complete without a free and fetterless mental state, which cultivates life with rough satisfaction and instructs people to value the original delicacy of it .

One more poem of this type is "Loam",[4] The view this poem presented bears a close resemblance to the rural life of China, where the peasants begin work at sunrise and rest at sunset. Loam runs on in a tone of a farmer who tells his simple daily routine to the audience. When dusk comes and the loam cools off with the darkness of the night, "we" have "our" rest in the loam and recollect the past old days. And by the first ray of the sun in the morning, "we" catch up with "our" work again, and thus a day. "Our" life is as simple as the loam, and "we" feel satisfied, for what "we" need is all there in the loam.

Life is enjoyable as much as the mind is determined to be. Sandburg made it clear in these poems that life is naturally beautiful beneath the plain cover of simplicity. And one shall have his dream of happiness fulfilled when he finds this open secret.

To feel content about life as it is, to listen to the wind, to admire a petal of a flower, to lie on the loam and to rest the mind a little, one will be surprised to notice that life is far more beauteous than he has ever known. The point here is, beauty does exist, and almost in every single common item. And as long as the mind is willing to make a beautiful discovery, the eyes will be honored to be the beauty hunter.

In the third type of BLIR, Diderot suggested that the sentiment of the subject is a matter of importance to the art of beauty. He did not conclude which kind of feeling is the most important one in the course of beauty process, and Sandburg didn't either. But Sandburg did value "a mind at ease" a lot in the discovery and appreciation of beauty. And as "ease" is a kind of feeling, they two would reach some agreement here.

Through those poems, Sandburg sent a message to his fellow countrymen that simple life is lovable and enjoyable and worthwhile to live. 


\section{V.CONCLUSION}

Sandburg was an extraordinary persona of the 20th century, that he was a great writer who made a brilliant contribution to American literature. ${ }^{[6]}$ To Carl Sandburg, his aesthetic thoughts behind his nature poems are, beauty lies in the beautiful itself, it emerges in connections, and it rests in ease, and they implicit his love towards nature and life. On the whole, Sandburg emphasized on simplicity: simple beauty, simple life, and simple mind. And by doing so, he voiced for the simple folks. Speaking of the similarities of Sandburg's aesthetic thoughts and that of Diderot, they two do have something in common. They both admired the spirit of the child, appreciated the simple beauty of nature, and they both recognized the beauty created through relation(s). And in addition to that, they both love life and nature, which is the origin of all those similar viewpoints. All in all, Sandburg's nature poems do embody the voice of the ordinary people and present an artistic enjoyment for the readers, and the aesthetic ideology behind those poems are worth a research effort.

\section{REFERENCES}

[1] Biography of Carl Sandburg, unpublished.

[2] C. YaoXin, L.YiXie, Selected Readings in American Literature (volume II). Tianjin: Nankai University Press, 1991.

[3] Denis Diderot, unpublished.

[4] Carl Sandburg's poems, unpublished.

[5] W. G. Moss, "The Wisdom of Carl and Paula Sandburg", unpublished.

[6] M. Xianzhong, "A Giant of the World Literature --Carl Sandburg," in Literature, vol. V, J.Li, Eds. Beijing:Foreign Literature ,1996, pp.56-60.(in Chinese) 